\title{
Polarographic Studies with the Improved Dipping Type Molybdenum Microelectrode.
}

\author{
III . Polarography in Fused NaF-KF-LiF Ternery Eutectic.* \\ By
}

\author{
Makoto SAITO ${ }^{\dagger}$
}

The Research Institutes for Iron, Steel and Otheer Metals,

Tohoku University, Sendai, Japan,

(Received May 30, 1964)

The polarogram of lead(II) ion in fused NaF-KF-LiF ternery eutectic medium was obtained by using an improved dipping type molybdenum microelectrode. The polarogram obtained had an Sshaped form without a knick, and resembled to that in the fused chloride media. The log plot of the current-voltage curve showed a linear relation between applied voltage against $\log \left(i_{d}-i\right) / i$, in spite of the fact that applied voltage against $\log \left(i_{d}-i\right)$ did not produce a straight line. The halfwave potential was $-0.55 \pm 0.01 \mathrm{~V}$. vs. molybdenum anode. The limiting curernt was found to be proportional to the concentration of lead(II) ion ranging from $1.95-4.60 \mathrm{~m}$ mol. per $1000 \mathrm{~g}$ fused salt.

\section{Introduction}

It had not been possible to carry out the polarography of metal ions in a medium of fused fluoride salts because of the generally high melting points of fluoride salts and because of their strongly corrosive action. However, a good polarogram of a metal ion was obtained by using an eutectic mixture of sodium fluoride-potassium fluoride-lithium fluoride as the fused salt solvent, as proposed by Bergman et al. ${ }^{1)}$ The advantage of this solvent are its good thermal stability, the wide span of its electrolytic decomposition potential, its high conductivity and fluidity, and the commercial availability of its components as reagent-grade salts. Further, its melting point is the lowest of all the fluorides, and its chemical reactivity is such that highly pure alumina is stable enough to be utilized as a material for constructing the electrolytic vessels. The properties of the solvent thus permit, in principle, a study of the electrochemistry of a wide variety of solutes with a minimum of interference from solvent effects and with only moderate experimental difficulty as high-temperature work goes.

In the present work, the dipping-type microelectrode, described in a previous report ${ }^{2}$, was modified for the fluoride bath and the polarography of lead(II) ion in this solvent was studied.

\section{Experimental}

\section{Apparatus and equipments used in fused salt methodology.}

II-1.1. Polarographic instrument. The DG polarograph used was the same apparatus as described in previous report. $\left.{ }^{2}\right)$

* This paper was issued in the Bulletin of the Chemical Society of Japan, Vol. 37, No. 2 P. 288 (1964), as a short communications.

$\dagger$ Present adiress : Department of Chemistry, College of General Education, Tohoku University, Sendai, Japan. 
II-1.2. Electrolytic cell. In fluoride bath, quartz can not be used but a high purity alumina is comparatively stable at the high temperature. Therefore, the high purity alumina cell (99.8 per cent), $48 \mathrm{~mm}$ in diameter and $300 \mathrm{~mm}$ in length, as shown in Fig. 1 (A), was used as the outer cell. The inner cell, in which the melt was placed, was made of high purity alumina, $25 \mathrm{~mm}$ in diameter and $150 \mathrm{~mm}$ in length, and was inserted in the outer cell. Dipping type molybdenum microelectrode was positioned in the melt with the movable shaft seal.

\section{II-1.3. Description of electrodes.}

(a) Dipping type molybdenum microelectrode. As shown in Fig. 1(B), a high purity graphite ring which is stable in fluoride melts and prepared easily, was sealed at the tip of the electrode.

(b) Reference electrode. A reference electrode for fluoride bath was proposed by Coriou $\left.e t a l .^{3}\right)$ but it has not been used practically because of the complicated design and of the difficulty in use.

(c) Anode. Metallic molybdenum plate $(15 \times 50 \times 0.1 \mathrm{~mm})$ was used as an anode.

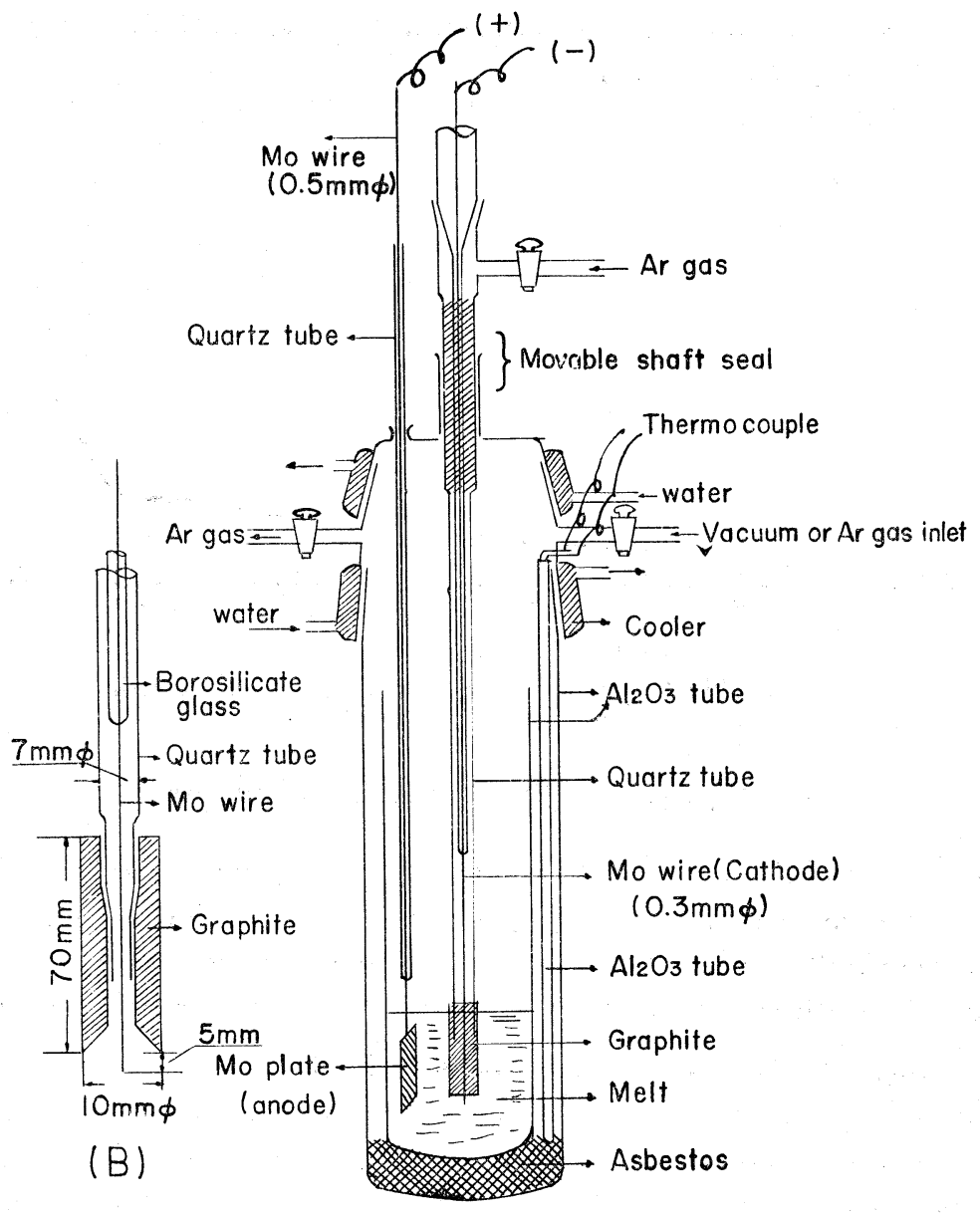

(A)

Fig. 1. Cell assembly used in fused fluoride salt polarography. 
II-2. Reagents.

Reagents used for the experiment were all of the grade of analytical use.

II-3. Preparation and purification of the eutectic salt of potassium fluoride-sodium fluoride-lithium fluoride ternery system.

The composition of sodium fluoride-potassium fluoride-lithium fluoride ternary system ${ }^{1)}$, which has the lowest eutectic point $\left(454^{\circ} \mathrm{C}\right)$, is sodium fluoride 11.5 , potassium fluoride 42 and lithium fluoride 46.5 mole per cent, or 11.7, 59.2 and 29.1 per cent by weight, respectively. In the present study, the composition described above was used as the fluoride bath and it was prepared as follows. Sodium fluorde, potassium fluoride and lithium fluoride were separately dried in a vacuum desiccator at $10^{-2}-10^{-3} \mathrm{~mm} \mathrm{Hg}$ for $1-2$ weeks. A mixture of 11.5 mole per cent sodium fluoride, 42 mole per cent potassium flouride and 46.5 mole per cent lithium fluorde was placed in an alumina cell and heated in an electric furnace, while evacuating at $10^{-2}-10^{-3} \mathrm{~mm} \mathrm{Hg}$. The temperature was raised to fuse the salts and maintained at $850-900^{\circ} \mathrm{C}$ for $1.5-3.0$ hours. The furnace temperature was then adjusted to the temperatured required for the polarographic operations $\left(650 \pm 2^{\circ} \mathrm{C}\right)$.

Residual current obtained with the mixture prepared by the foregoing method is shown in Fig. 2. The terminal voltage corresponding to the final current ascending was about $-2.1 \mathrm{~V} . v s$. molybdenum, anode.

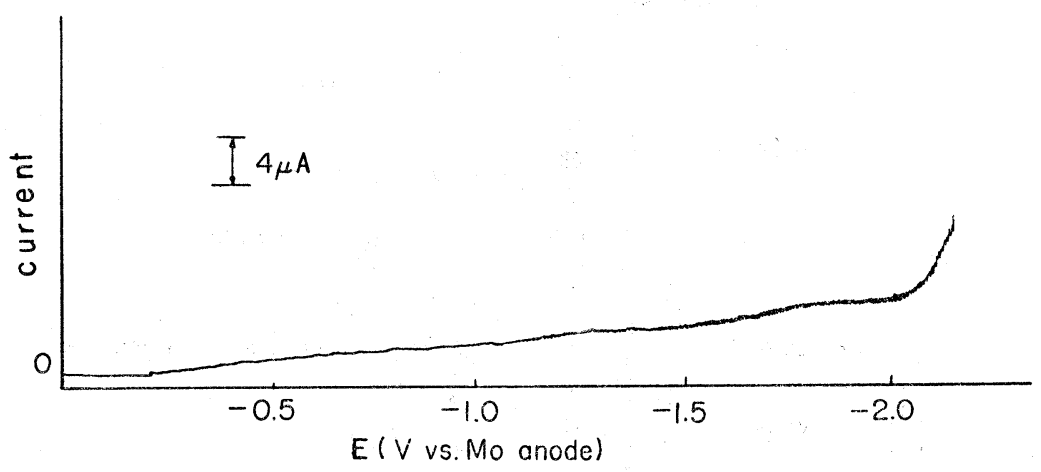

Fig. 2. Residual current in the fused NaF-KF-LiF eutectic.

\section{Experimental Results and Considerations}

\section{II-1. Relationship between the Concentration of lead(II) ion and the limiting current.}

Lead(II) ion in the concentration range of 1.95 to $4.60 \mathrm{~m}$ mol. per $1000 \mathrm{~g}$. fused salt was used and the result is shown in Fig. 3. As will be seen from Fig. 3, the limiting current was found to be directly proportional to the concentration in the above range.

III-2. Current-voltage curve and half-wave potential of lead(II) ion

A typical polarogram of lead(II) ion in this fused salt is shown in Fig. 4, (a). The wave form is similar to that obtained in previous report ${ }^{2}$.

The log plot of the current-voltage of the polarogram of lead(II) ion is shown in Fig. 4(b). It was found that the plot of the applied voltage against $\log \left(i_{d}-i\right) / i$ yielded a straight line, although the plot agaist $\log \left(i_{d}-i\right)$ did not. The half-wave potential was $-0,55 \pm 0,01$ 


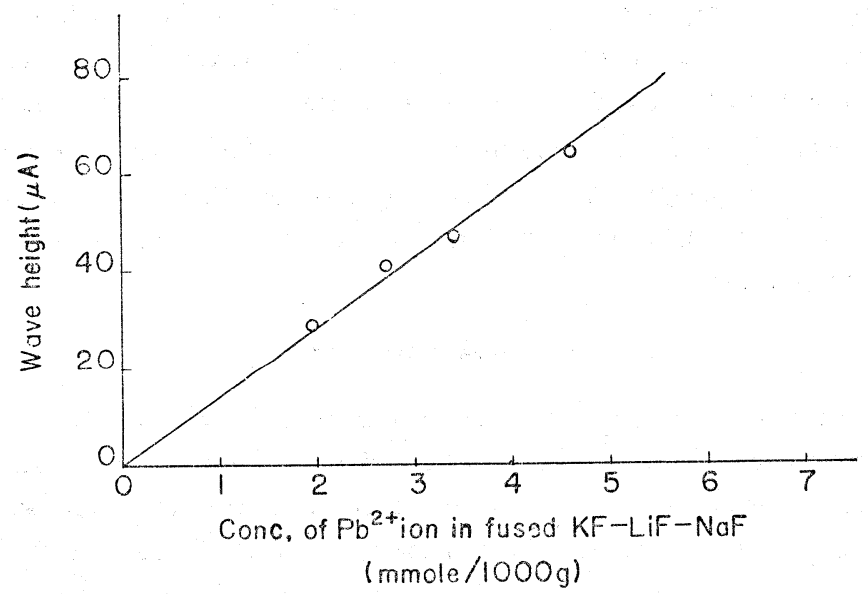

Fig. 3. Relationsnip between concentration of lead (II) ion and limiting current.

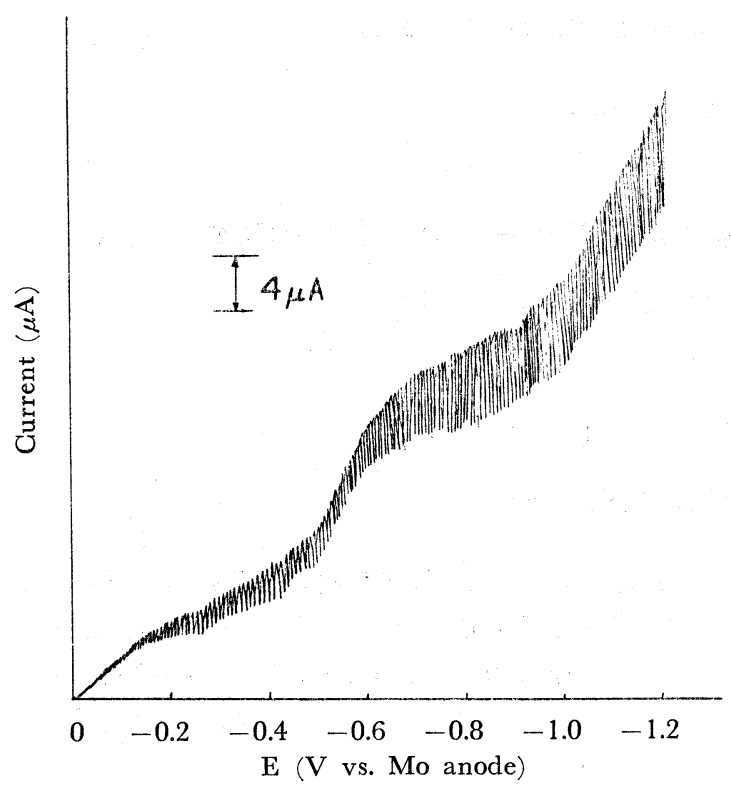

Fig. 4(a.) Polarographic wave of lead (II) ion in fused NaF-KF-LiF eutectic.

$\mathrm{V} v s$. the molybdenum anode. These characteristics can be clarified if one assumes a totally irreversible reduction process, as discussed in the previous report ${ }^{2}$.

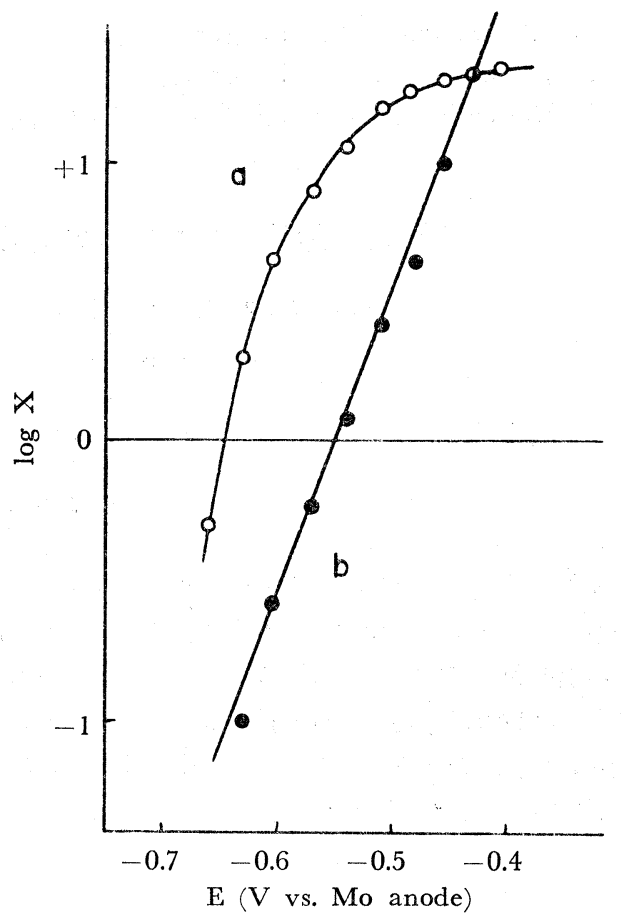

Fig. 4(b). The log plots of the currentvoltage curve of lead(II) ion in fused NaF-KF-LiF eutectic.

Curve a : $X=\left(i_{d}-i\right), b: X=\left(i_{d}-i / i\right)$

\section{Conclusion}

The author improved the dipping type microelectrode for the plarography in fluoride bath and good polarograms of lead(II) ion in fused fluorde, were obtained.

The polarogram obtained had an S-shaped from without a knick, and resembled to that in the fused chloride. The log plot of the current-voltage curve showed a linear rela- 
tion between applied voltage against $\log \left(i_{d}-i\right) / i$, in spite of the fact that applied voltage against $\log \left(i_{d}-i\right)$ did not produce a straight line. The half-wave potential was $-0.55 \pm$ $0.01 \mathrm{~V}$. vs. the molybedenum anode. The limiting current was found to be proportional to the concentration of lead(II) ion ranging from 1.95 to $4.60 \mathrm{~m}$ mol. per $1000 \mathrm{~g}$ fused salt.

The present results suggest that the polarograms of other metal ions in the fluoride melt may be obtained by using this electrode and, studies of electrochemical behaviors of metal ions may be possible.

\section{Acknowledgemens}

The author expressed his gratitude to Professors Hidehiro Gotô and Shin Suzuki of the Research Institutes for Iron, Steel and Other Metals, Tohoku University, for their helpful discussions and criticisms on the experimental work and preparation of manuscript. The author also expressed his thanks to Professor Tomihito Kanbara of the Department of Chemistry, Hokkaido Univesity who gave many valuable suggestions.

\section{Literature}

1) A.G. Bergman, E.P. Dergnnov, Compt. rend. akad. sci. URSS., 31, 754 (1941).

2) M. Sato, Rev. of Polarography,

3) H. Coriou, J. Dirian, J. Hure, J. Chem. phys., 52, 479 (1955).

\section{改良浸漬型モリブデン微小電極に関するポーラログラフ的研究}

（III） 溶融フッ化ナトリウムーフッ化カリウムーフッ化リチウム 3 元共融体中の鉛（II）イオンのポーラログラフィー

斉、藤節

(東北大学金属材料研究所)

従来おてなわれていないフッ化物浴中の $\mathrm{Pb}^{2+}$ のポ ーラログラフィーについて, 改良浸漬型モりブデン微 小電極を用いて検討した。 その結果， $-0.55 \mathrm{~V}$ vs. Mo 陽極に半波電位を有する再現性あるポーラログラムが 得られた，乙のポーラログラムの波高は $\mathrm{Pb}^{2+}$ の濃度 に比例するととが確められた。 また，乙の電流一電圧
曲線のE〜 $\log \left(i_{d}-i\right) / i$ の関係が直線を予えるのに対し て $\mathrm{E} 〜\left(i_{d}-i\right)$ は曲線であることなどが知られた。乙れ らの実験結果から本電極を用いてフッ化物浴中の種々 の金属イオンのポーラログラフ的研究が可能であると とが確められた。 